\title{
PENGARUH SELF-MANAGEMENT TERHADAP PRESTASI BELAJAR MAHASISWA STAB KERTARAJASA, BATU
}

\author{
Kadek Jaya Sumanggala ${ }^{1}$, Wina Dhamayanti ${ }^{2}$, Adji Sastrosupadi ${ }^{3}$ \\ E-mail: boddhicaro78@gmail.com ${ }^{1}$, winadhamma@gmail.com ${ }^{2}$, sastroadji8@ \\ gmail.com ${ }^{3}$ \\ Pendidikan Keagamaan Buddha, Sekolah Tinggi Agama Buddha (STAB) \\ Kertarajasa \\ Jalan Ir. Soekarno Nomor 311, Batu 65322
}

\begin{abstract}
Abstrak: Penelitian ini bertujuan untuk mengetahui tingkat dan pengaruh Self-management terhadap prestasi belajar mahasiswa Samanera/ Atthasilani dan reguler STAB Kertarajasa. Penelitian ini merupakan penelitian kuantitatif dengan variabel bebas adalah Self-management dan prestas belajar sebagai variabel terikat. Subjek dalam penelitian ini adalah mahasiswa yang berjumlah 28 orang. Metode pengambilan data yang digunakan adalah skala Self-management dan nilai Indeks Prestasi Komulatif. Teknik analisis data penelitian ini menggunakan analisis Uji t dan skala likert. Hasil penelitian ini menunjukkan bahwa Self-management berpengaruh sangat efektif terhadap prestasi belajar, jika ditinjau dari persentase capaian sebesar 76\%. Berdasarkan analisis uji t nilai IPK Samanera/ Atthasilani dan Reguler menunjukkan bahwa ada perbedaan yang nyata antara IPK mahasiswa Samanera/ Atthasilani dengan reguler karena $t$ hitung $(2,564)>\mathrm{t} 0,05=2,056<\mathrm{t} 0,01(=2,779)$. Perbedaan IPK mahasiswa Samanera/Atthasilani dengan reguler mengindikasikan bahwa tingkat management Samanera/Atthasilani lebih tinggi. Hal ini karena terdapat perlakuan terhadap pola kehidupan yang berbeda, dimana Samanera/Atthasilani terikat dengan peraturan yang menyebabkan pola kehidupan lebih teratur dan reguler dengan pola kebebasan yang ada mereka akan lebih bebas untuk menjalankan aktivitasnya.
\end{abstract}

Kata Kunci : mahasiswa Samanera/Atthasilani, mahasiswa regular, prestasi belajar, self-management

\section{THE EFFECT OF SELF-MANAGEMENT ON STAB KERTARAJASA STUDENTS' LEARNING ACHIEVEMENT, BATU}

\begin{abstract}
This study aims to determine the level and influence of self-management on learning achievement of students with Samanera/Atthasilani status and regular students of STAB Kertarajasa. This research is a quantitative research. The variables of this study include self-management (independent variable) and learning achievement (dependent variable). The subjects in this study were 28 students. The data retrieval method used is the Self-management scale and the value of the Cumulative Achievement Index. The data analysis technique of this research used $t$ test analysis and Likert scale. The results of this study indicate that self-management has a very effective effect on learning achievement, when viewed from the percentage of achievement of $76 \%$. Based on the $t$-test analysis of Samanera/Atthasilani and Regular IPK values, it shows that there is a significant difference between the IPK of Samanera/Atthasilani students and regular students because t count $(2.564)>t 0.05=2.056$ $<t 0.01$ (=2.779). The difference in the IPK of Samanera/Atthasilani students with regular students indicates that the management level of Samanera/Atthasilani is higher. This is because there is treatment of different patterns of life, where Samanera/Atthasilani are bound by regulations that cause a more regular and regular pattern of life with the existing pattern of freedom they will be more free to carry out their activities.
\end{abstract}

Keyword: Samanera/Atthasilani, students, regular students, learning achievement, self-management 


\section{PENDAHULUAN}

Menempuh pendidikan di Perguruan Tinggi tidaklah semudah apa yang dipikirkan. Banyak sekali pekerjaan, tantangan, tuntutan yang dihadapi dan harus dijalankan sebagai mahasiswa. Pekerjaan, tantangan dan tuntutan tersebut di antaranya adalah pembuatan berbagai macam tugas, laporan, makalah, maupun ujian yang merupakan bentuk evaluasi bagi mahasiswa serta tugas-tugas akademik lainnya. Berbagai hal dan situasi juga dapat memengaruhi keberhasilan prestasi mahasiswa (Lestariningsih, 2007).

Begitu pula mahasiswa reguler memiliki kesibukan di luar kampus seperti, bekerja. Kuliah sambil bekerja bukanlah hal baru di kalangan mahasiswa. Menurut Cohen (Yenni, 2007) bentuk pekerjaan yang paling banyak dilakukan oleh mahasiswa adalah jenis pekerjaan paruh waktu (part-time work). Beragam alasan melatarbelakangi mahasiswa kuliah sambil bekerja, mulai dari masalah ekonomi sampai hanya karena ingin mengisi waktu luang. Selain itu tidak jarang mahasiswa reguler juga tergabung ke dalam organisasi-organisasi seperti halnya Badan Eksekutif Mahasiswa (BEM) sehingga mahasiswa harus membagi waktu antara mengikuti kegiatan keorganisasian dan menuntut ilmu di kampus.

Sepadat apapun kegiatan yang dimiliki, mahasiswa dituntut untuk dapat beradaptasi dan mengelola diri dengan baik agar prestasi dalam belajar mendapatkan hasil memuaskan di samping mengikuti kegiatan-kegiatan di luar kampus. Dari uraian di atas self-management merupakan salah satu faktor penting yang harus dimiliki oleh mahasiswa agar meraih prestasi belajar yang lebih baik, karena self-management sangat berpengaruh terhadap prestasi belajar mahasiswa. Mahasiswa Samanera/Atthasilani dan mahasiswa reguler masing-masing memiliki kesibukan, dengan peraturan, kegiatan vihara, dan juga tugas perkuliahan. Terkait adanya peraturan bagi Pabbajita sebagai berikut: a. semua Samanera wajib menaati dasa sila dan Samanera sikkha secara berkesadaran, b. Atthasilani menaati Atthasila dan peraturan tata tertib Atthasilani secara berkesadaran, c. Samanera dan Atthasilani menaati peraturan tata tertib Pabbajita Padepokan Dhammadipa Arama guna mewujudkan kedisiplinan hidup, d. selama kuliah 4 tahun, Pabbajita secara prinsip tidak dikehendaki melepas jubah atas kemauan sendiri, dan e. pengabdian Dhamma: a). sebagai rasa terima kasih atas dukungan umat dalam memberikan beasiswa selama 4 tahun, maka Pabbajita diwajibkan memberikan pengabdiannya kepada umat Buddha di daerah yang dikoordinir oleh Dewan Pimpinan Sangha Theravada Indonesia (Ningsih, 2018).

Prokrastinasi akademik jika dilakukan akan banyak berakibat negatif, dengan melakukan penundaan, banyak waktu yang terbuang dengan sia-sia. Tugas-tugas menjadi terbengkalai, bahkan bila diselesaikan hasilnya menjadi tidak maksimal. Penundaan juga mengakibatkan seseorang kehilangan kesempatan dan peluang yang datang. Penelitian yang dilakukan oleh Aitken (Rachmahana, 2002) menyatakan bahwa prokrastinasi yang terjadi dalam masyarakat pada umumnya berkisar 25\% sampai $70 \%$. Menurut Yuen (2008), ada sekitar 75\% dari mahasiswa universitas di Amerika serikat melakukan prokrastinasi, sedangkan $50 \%$ dari mahasiswa melaporkan diri sebagai pelaksana prokrastinasi secara terus-menerus dan 50\% menganggap hal ini sebagai masalah. Penelitian dari Bruno (Anwar, 2017) juga mengungkapkan bahwa ada $60 \%$ individu memasukkan sikap menunda sebagai kebiasaan dalam hidup mereka.

Maka dari itu self-management sangat penting untuk ditanamkan dan dilatih pada individu masingmasing. Apabila tidak ditanamkan maka mereka akan kesulitan untuk membagi waktu serta menata hidupnya dengan baik. Seseorang akan dituntut untuk menghadapi permasalahan-permasalahan yang ada. Semakin dewasa seorang individu maka akan banyak juga permasalahan yang dihadapi.

Penelitian terdahulu yang dilakukan oleh Suagian Nurwijaya (2018) yang mengkaji tentang hubungan manajemen diri dengan prestasi belajar menunjukkan adanya korelasi yang signifikan antara manajemen diri dengan prestasi belajar matematika siswa kelas VIII SMP di Watampone, tahun ajaran 2018/2019. Tingkat hubungan manajemen diri dengan prestasi siswa sedang, dilihat dari correlation dengan nilai $(r=0,440)$ yang berapa pada nilai $r=0,40$ 0,599 . Sedangkan penelitian yang dilakukan oleh Agustiningrum \& Kusbaryanto (2019) berusaha mengungkap pengaruh manajemen diri terhadap peningkatan perawatan diri bagi orang yang terkena diabetes dan diketahui bahwa penggunaan diabetes self-management education efektif terhadap peningkatan perawatan diri pada pasien diabetes mellitus.

Berdasarkan latar belakang masalah yang sudah diuraikan, maka penelitian ini berusaha mengungkap tingkat self-management mahasiswa (Samanera/Atthasilani dan reguler STAB kertarajasa) dan bagaimana pengaruh self-management terhadap 
prestasi belajar mahasiswa (Samanera/Atthasilani dan regular) di STAB kertarajasa. Bagi institusi, penelitian ini diharapkan dapat dijadikan sebagai bahan masukan untuk institusi dan dosen bahwa pemberian pengetahuan self-management kepada mahasiswa perlu diberikan ruang dan waktu, sehingga akan berpengaruh terhadap kelancaran proses belajar mengajar, kedua mahasiswa dapat mengetahui bahwa pentingnya self-management yang mengandung nilai-nilai dalam menunjang perkembangan dan memaksimalkan potensi yang dimiliki mahasiswa. Maka dengan pemahaman tersebut mahasiswa dapat terdorong untuk selalu mengelola dirinya dengan baik agar kemampuan kognitif, afektif, dan psikomotor sehingga mampu mencapai tujuan. Selain itu dapat menambah wawasan, pola pikir, serta pengalaman dan hasil penelitian ini dapat menjadi bahan kajian untuk penelitian selanjutnya.

\section{A. Pengertian Self-management}

Self-management merupakan istilah yang umum dipakai untuk menggambarkan kemampuan individu dalam mengorganisir kapasitas-kapasitas mental dalam mencapai tujuan (goal). Dalam kajian psikologi, istilah yang lebih tepat menggambarkan self-management adalah self-regulation atau pengaturan diri yang dikemukakan oleh Albert Bandura untuk mendeskripsikan bahwa manusia dapat berfikir dan mengatur tingkah lakunya sendiri; sehingga mereka bukan semata-mata menjadi objek pengaruh lingkungan (Jazimah, 2014). Lebih lanjut menurut Ormrod (Jazimah, 2014), kemampuan regulasi diri merupakan kemampuan yang dimiliki oleh setiap manusia, yang perlu dikembangkan dan diarahkan, karena perilaku yang dihasilkan oleh regulasi diri ini tidak bisa terjadi secara alamiah.

Beberapa ahli seperti Sarafino (2010) mendefinisikan self-management menjadi modifikasi, yakni perilaku sebagai karakteristik yang menyebabkan perkembangan prilaku dan menggunakan prinsip pembelajaran. dalam usaha memodifikasi prilaku diperlukan kontrol pada pengambilan keputusan dan tindakan-tindakan. Menurut Frayne \& Geringer (2000) seseorang yang memiliki self-management yang efektif, maka individu akan dapat mencapai tujuan yang dicapai. Hal ini karena individu yang memiliki manajemen yang efektif akan mampu memaksimalkan potensi-potensi dirinya baik potensi dari dalam maupun dari luar dirinya.

Dari uraian di atas dapat disimpulkan bahwa self-management merupakan suatu upaya yang dilakukan oleh individu dalam mencapai tujuan yang dirumuskan dengan cara mengelola, mengatur, dan memaksimalkan potensinya. Kemampuan tersebut sangat penting dalam mempermudah mencapai tujuan.

\section{B. Faktor-faktor Self-management}

Faktor yang dapat memengaruhi selfmanagement, antara lain yaitu faktor lingkungan seperti dikemukakan Prijosaksono (Khoiratunnisaa, 2016), faktor penting yang dapat mempengaruhi selfmanagement yaitu lingkungan. Lingkungan sosial yang menyenangkan, sikap atau respon dari lingkungan akan membentuk sikap terhadap diri seseorang (self attitude). Selain faktor lingkungan, menurut Pedler dan Boydell (Khoiratunnisaa, 2016) terdapat faktor lain yang memengaruhi self-management, yakni:

1. Kesehatan (health)

Kondisi fisik maupun mental dapat mempengaruhi seseorang dalam mengarahkan aktivitas dalam kehidupan. Kesehatan fisik menjadi modal utama bagi seseorang untuk dapat melakukan aktivitas dan di sisi lain kesehatan mental akan menciptakan kondisi $\mathrm{t} \mathrm{u} \mathrm{b} \mathrm{u} \mathrm{h} \quad \mathrm{y}$ a $\mathrm{ng} \quad \mathrm{s} \mathrm{t} \mathrm{a}$ b i 1 .

2. Keterampilan (skill)

Seseorang dapat memutuskan untuk memiliki beberapa keahlian sekaligus (multy skills) atau memutuskan untuk hanya fokus menentukan satu keahlian saja. Pilihan tertentu yang dilakukan oleh seseorang selanjutnya akan memengaruhi upaya mewujudkan tujuan yang sudah disusun sedemikian rupa ( $\mathrm{K}$ h o i r a $\mathrm{unn}$ is a , 2016 ).

3. Aktivitas (action)

Individu yang mampu menyelesaikan dan mengembangkan aktivitas hidupnya adalah individu yang memiliki kepekaan terhadap berbagai alternatif atau cara pandang dan memiliki imajinasi moral yang tinggi, sehingga keputusan aktivitasnya mempertimbangkan dua hal sekaligus yaitu yang memberikan manfaat bagi dirinya dan orang lain ( $\mathrm{R}$ e $\mathrm{n} \mathrm{g} \mathrm{g} \mathrm{i} \mathrm{n} \mathrm{a} \mathrm{s}, \quad 2005$ ). 4. Identitas diri (identity)

Identitas diri juga disebut dengan konsep diri. Seberapa jauh pengetahuan, pemahaman, dan penilaian seseorang terhadap keadaan dirinya akan mempengaruhi cara-caranya bertindak (Khoiratunnisaa, 2016).

\section{Aspek-aspek Self-management}

Menurut The Liang Gie (2000) terdapat empat aspek self-management, yakni: pendorong diri (self- 
motivation), penyusunan diri (self organization), pengendalian diri (self-control), dan pengembangan diri (self-development).

\section{Pendorongan diri (self-motivation)}

Self-motivation merupakan dorongan batin yang terdapat dalam individu sebagai rangsangan sehingga mampu bergerak untuk melakukan berbagai kegiatan untuk mencapai tujuan yang diinginkan. Dengan adanya dorongan dari dalam diri individu tanpa dorongan orang lain akan menumbuhkan minat dan semangat untuk belajar yang kuat dalam menjalankan kegiatan untuk mencapai tujuan (Gie, 2000). Suatu dorongan dari orang lain akan kuat kalau timbul karena diri sendiri $\mathrm{k}$ e $\mathrm{t} \mathrm{i} \mathrm{m} \mathrm{b} \mathrm{a} \mathrm{g} \mathrm{d} \mathrm{a} \mathrm{r} \mathrm{i} 1 \mathrm{u}$ a r.

\section{Penyusunan diri (self-organization)}

Menurut Gie (2000) penyusunan diri (selforganizing) adalah pengaturan sebaik-baiknya terhadap pikiran, tenaga, waktu, tempat, benda, dan semua sumber daya lainnya dalam kehidupan seorang siswa sehingga tercapai efisiensi pribadi. Apabila segala sesuatunya telah diatur sebaik mungkin, maka akan tercapai kehidupan yang lebih efisien.

3.Pengendalian diri (self-control)

Definisi pengendalian diri (self-control) menurut Gie (2000) yaitu perbuatan manusia membina tekad untuk mendisiplinkan kemauan, memacu semangat, dan mengarahkan tenaga untuk benar-benar melaksanakan apa yang harus dikerjakan di sekolah. Kecenderungan bermalas-malasan, keinginan mencari gampangnya, kesenangan berjerih payah melakukan kosentrasi, kebiasaan menundanunda pelaksanaan tugas, belum lagi berbagai gangguan perhatian lainnya seperti acara televisi, iklan film, atau ajakan teman senantiasa menghinggapi kebanyakan peserta didik. Dari semua aktivitas yang kurang bermanfaat dapat dihindari dengan pengen-

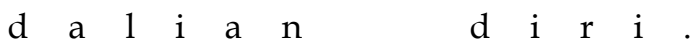
Adanya pengendalian diri yang kuat akan memunculkan tekad atau keinginan yang kuat untuk melaksanakan apa yang seharusnya dikerjakan. Di samping itu, keinginan yang kuat akan memacu semangat tinggi untuk memperoleh cita-cita. Pengendalian diri akan menjauhkan individu dari hal-hal yang tidak penting dan memprioritaskan segala sesuatu untuk mencapai tujuan. 4.Pengembangan diri (self-development)
Gie (2000) mengemukakan bahwa pengembangan diri adalah perbuatan menyempurnakan atau meningkatkan diri sendiri dalam berbagai hal. Pengembangan diri yang lengkap dan penuh mencakup segenap sumber daya pribadi dalam seorang peserta didik, $\begin{array}{llllll}y & a & i & t & u & \text { : }\end{array}$

a. Kecerdasan pikiran: untuk menambah kearifan pengetahuan dan keterampilan yang be r g n a d a l a m h d u p .

b.Watak kepribadian: untuk membina budi yang luhur dan perilaku yang susila.

c. Rasa kemasyarakatan; untuk menumbuhkan hasrat memajukan masyarakat dan membantu orang lain yang kurang beruntung dalam

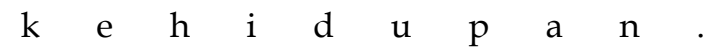

d.Untuk memelihara kesehatan jasmani maupun kesejahteraan rohani.

\section{Ciri-ciri Self-management}

Agar dapat mengendalikan diri secara langsung maka individu dapat menciptakan atau mengubah isyarat berupa benda, barang, atau hal yang ada di sekitar individu tersebut untuk memengaruhi perilakunya. Menurut Kanfer (Suhartini, 1992) terdapat ciri-ciri individu yang memiliki self-management yaitu:

1. Menentukan sasaran (Goal Setting), yaitu menentukan sasaran, target tingkah laku, prestasi yang hendak dicapai merupakan langkah pertama dari program self-manage ment dalam belajar. Penetapan tujuan agar dapat mengarahkan seseorang atas tujuan apa yang hendak dicapai. Tujuan sebagai mahasiswa tentunya memiliki prestasi, entah prestasi akademik maupun prestasi non a $\mathrm{k} \quad \mathrm{a} \quad \mathrm{d} \quad \mathrm{e} \quad \mathrm{m} \quad \mathrm{i} \quad \mathrm{k}$.

2. Memonitor diri sendiri (self monitoring), bentuk aplikasi dari memonitor diri bisa dengan cara mencatat atau membuat grafik dari data yang biasa dilihat oleh individu yang bersangkutan sehingga dapat berfungsi sebagai feed back intensi dan juga sebagai penguat (reinforce).

3. Mengevaluasi diri sendiri (evaluating), tahap evaluasi terhadap perkembangan diri dari rencana kerjanya, apakah targetnya tercapai atau tidak dan apa-apa saja yang harus diperbaiki dalam mencapai sasaran.

4. Proses penguatan diri (self reinforcement), teknik memberikan penghargaan kepada diri sendiri secara positif. 
Kebahagiaan merupakan dambaan setiap orang karena tidak seorang pun ingin hidup menderita. Pada umumnya hidup bahagia ketika seseorang mendapatkan apa yang diinginkan, sebaliknya ketika apa yang diinginkan tidak tercapai maka muncul penderitaan. Motivasi dapat terjadi apabila terdapat unsur keyakinan (saddha). Keyakinan merupakan suatu sikap batin yang mendorong seseorang untuk melakukan tindakan sesuai apa yang diyakini. Buddha menjelaskan dalam Samyutta Nikaya (Bodhi, 2000) keyakinan merupakan benih yang digunakan untuk mencapai kebahagiaan. Saddha sebagai tingkatan pertama dalam faktor usaha untuk mencapai keberhasilan. Landasan awal untuk meraih kesuksesan adalah dengan memiliki saddha serta didukung dengan adanya usaha keras. Seperti petapa Gotama yang sangat gigih dan tekad yang sangat kuat untuk mencapai cita-titanya untuk menjadi Buddha. Setelah tercapai tujuannya selama empat puluh tahun Buddha membabarkan dhamma dengan semangat dan setiap hari beliau melakukan kegiatan rutin-Nya tanpa mengenal jenuh. Kegiatan harian yang dilakukan Buddha dapat dibagi menjadi lima sesi, yaitu: (1) kegiatan pagi (purebhatta kicca), (2) kegiatan siang (pacchabhatta kicca), (3) kegiatan waktu jaga pertama malam (purimayama kicca), (4) kegiatan waktu jaga pertengahan malam (majjhimayama kicca), dan (5) kegiatan waktu jaga terakhir malam (pacchimayama kicca) (Sayadaw, 2008).

Untuk menjadi bahagia seseorang harus mampu mengendalikan pikiran, ucapan, dan badan jasmaninya. Dalam Dhammapada XVII:17:14 dikatakan bahwa Kayena samvuta dhira atho vacaya samvuta manasa samvuta dhira te ve suparisamvuta orang bijaksana mengendalikan perbuatan melalui badan jasmani, mereka mengendalikan perbuatan melalui ucapan, mereka mengendalikan pikiran dengan baik, mereka yang menjaga ketiga pintu , badan jasmani, ucapan, pikiran, benar-benar telah mengendalikan diri dengan sepenuhnya (Penterjemah, 2013).

Pengendalian diri bukanlah hal yang mudah dilakukan, tetapi dengan memiliki pengendalian diri akan memberikan manfaat bagi diri sendiri dan orang lain. Dengan pengendalian diri akan menciptakan kehidupan yang harmonis dan damai, sejahtera, dan bahagia. Terdapat lima cara untuk pengendalian diri yang diuraikan Buddha dalam Visuddhimagga (Mehm, 2012), yaitu:

1.Sila samvara (pengendalian diri melalui

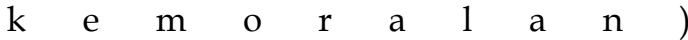

2.Sati-samvara (pengendalian diri melalui

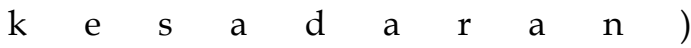

3.Nana-samvara (pengendalian diri melalui $\mathrm{p}$ a $\mathrm{n} \mathrm{d}$ a $\mathrm{n} \mathrm{g}$ a $\mathrm{n} \quad \mathrm{t}$ e $\mathrm{r}$ a $\mathrm{n} \mathrm{g}$ )

4. Khanti-samvara (pengendalian diri melalui $\left.\begin{array}{llllllllllll}\mathrm{k} & \mathrm{e} & \mathrm{s} & \mathrm{a} & \mathrm{b} & \mathrm{a} & \mathrm{r} & \mathrm{a} & \mathrm{n}\end{array}\right)$

5. Viriya-samvara (pengendalian diri melalui $\mathrm{us} \mathrm{a} \mathrm{h} \mathrm{a} \mathrm{a} \mathrm{ta} \mathrm{u}$ s e m a $\mathrm{ng}$ a $\mathrm{t}$ ) Buddha juga menguraikannya di dalam Karaniya metta sutta bait kedua yang berbunyi sebagai berikut "berpengendalian diri dengan merasa puas atas apa yang dimiliki, mudah dirawat, tidak repot, bersahaja hidupnya, indria tenang, penuh pertimbangan, dan sopan". Pesan yang disampaikan oleh Buddha tidak hanya cocok untuk seorang pabbajita tetapi sebagai upasaka dan upasika juga dapat mempraktikkan ajaran yang diberikan oleh beliau.

Setiap orang menginginkan ketenangan dan kebahagiaan, namun sedikit sekali orang yang berhasil mendapatkannya. Menaklukkan pikiran dan membawanya ke arah pemahaman yang benar akan kesunyataan bukanlah hal yang mudah. Untuk mencapai kondisi tenang dan bahagia perlunya mengembangkan mental yang bertujuan untuk membersihkan pikiran dari ketidakmurnian dan gangguan-gangguan, seperti nafsu keinginan, kebencian, niat buruk, kemalasan, kecemasan, kegelisahan dan keragu-raguan serta untuk mengembangkan kualitas-kualitas seperti konsentrasi, kesadaran yang kuat, kecerdasan, kekuatan kemauan, kemampuan analisis yang tajam, kesukacitaan, ketenangan, keseimbangan hingga mencapai kebijaksanaan tertinggi (Wijoyo, 2020).

Menurut Diputhera (2004) meditasi dalam bahasa pali disebut bhavana, yang berarti pengembangan. Seorang yang berlatih meditasi harus terlatih dalam Sila sebagai dasar pelaksanaan Samadhi. Sila dalam buku-buku agama Buddha sering diartikan sebagai moral, kumpulan asas atau nilai yang berkenaan dengan akhlak nilai mengenai benar atau salah yang dianut oleh suatu golongan atau masyarakat. Di dalam agama Buddha mengenal dua macam Samadhi yang pertama samatha bhavana (ketenangan batin) dan vipassana bhavana (pelenyapan kekotoran batin).

Menurut Kamus Besar Bahasa Indonesia (2014) bahwa "Prestasi adalah hasil yang telah dicapai". Prestasi belajar di bidang pendidikan adalah hasil dari pengukuran terhadap peserta didik yang meliputi faktor kognitif, afektif, dan psikomotor setelah mengikuti proses pembelajaran yang diukur dengan menggunakan instrumen tes atau instrumen yang relevan (Ariyanti, 2010).

Prestasi belajar pada dasarnya merupakan hasil 
belajar atau hasil penilaian yang menyeluruh, dengan meliputi (a) prestasi belajar dalam bentuk kemampuan pengetahuan dan pengertian, (b) prestasi belajar dalam bentuk keterampilan intelektual dan keterampilan sosial, dan (c) prestasi dalam bentuk sikap atau nilai (Syah, 2010). Menurut Saleh (Retnowati, Fatchan \& Astina, 2016) prestasi belajar merupakan hasil yang dicapai siswa dengan menguasai tingkat penguasaan ilmu pengetahuan tertentu dengan alat ukur berupa evaluasi yang dinyatakan dalam bentuk angka, huruf, atau simbol.

Berhasil tidaknya seseorang dalam belajar disebabkan oleh beberapa faktor mulai dari dalam diri maupun dari luar diri individu. Dalam proses belajar akan memengaruhi tingkat pencapaian belajar. Slameto (2003) mengatakan bahwa terdapat dua faktor yang memengaruhi prestasi belajar yakni, faktor internal dan faktor eksternal.

1. Faktor internal merupakan faktor yang terdapat dalam individu yang sedang belajar seperti: Faktor jasmaniah meliputi; (a) Faktor kesehatan (b) Cacat tubuh, Faktor psikologis meliputi (a) Intelegensi (b) Perhatian (c) Minat (d) Bakat (e) Motivasi (f) Kematangan (g) Kesiapan, Faktor Kele la ha n

2. Faktor Ekternal meliputi; (a) Keadaan keluarga (b) Keadaan sekolah (c) Keadaan ma$\mathrm{s} \quad \mathrm{y} \quad \mathrm{a} \quad \mathrm{r} \quad \mathrm{a} \quad \mathrm{k} \quad \mathrm{a} \quad \mathrm{t}$ Di sisi lain Bachri Djamarah (Basri, 2012) juga memberikan pendapatnya terkait dengan faktor-faktor prestasi belajar, yakni:

1. Faktor psikologis, meliputi minat, kecerdasan, bakat, motivasi, kemampuan kognitif (persepsi, mengingat, berfikir) dan ambisi. Faktor internal yang paling berpengaruh adalah faktor kognitif yang meliputi persepsi, mengingat, dan berfikir. Faktor persepsi sangatlah berpengaruh terhadap prestasi belajar individu karena persepsi pada hakekatnya merupakan asumsi dasar yang memengaruhi $\mathrm{p}$ e $\mathrm{r}$ i $\mathrm{l}$ a $\mathrm{k} \mathrm{u} \quad \mathrm{s}$ e s e o $\mathrm{r}$ a $\mathrm{n} \mathrm{g}$.

2. Faktor fisiologis, yaitu kondisi jasmani dan rohani, seperti postur tubuh, asupan gizi, kemudahan materi pelajaran yang diterima, serta kondisi panca indera (sempurna atau tidak), seperti kondisi penglihatan dan pen$\mathrm{d} \quad \mathrm{e} \quad \mathrm{n} \quad \mathrm{g}$ a $\mathrm{r}$ a $\mathrm{n}$.

Banyak faktor yang menyebabkan tinggi atau rendahnya prestasi belajar anak didik di antaranya faktor dalam diri maupun faktor luar diri, di mana keduanya akan saling memengaruhi prestasi belajar. Maka sangat penting kemauan untuk dapat berkembang melalui usaha individu dan lingkungan memberikan wadah dalam pengembangan diri.

Faktor-faktor tersebut di atas secara teori akan membantu mahasiswa untuk mencapai:

\section{Prestasi akademik}

Prestasi akademik yang dicapai tidak dapat dipisahkan dari proses belajar, karena prestasi akademik dipengaruhi oleh proses belajar itu itu sendiri. Proses belajar merupakan suatu usaha yang dilakukan oleh seseorang untuk memperoleh suatu pengetahuan dan perubahan tindakan secara keseluruhan sebagai hasil dari interaksi dengan lingkungan menurut Slameto (Prijana \& Yanto, 2018). Proses belajar tidak dapat dipisahkan dari prestasi belajar, karena proses merupakan kegiatan belajar sedangkan prestasi merupakan hasil dari proses pembelajaran. Menurut Warsito (Prijana \& Yanto, 2018) prestasi akademik ditandai dengan nilai-nilai optimal yang diperoleh dengan indikator IP (Indeks Prestasi) maupun IPK (Indeks Prestasi Kumulatif) serta ketepatan waktu dalam menyelesaikan studi sebagai bagian dari hasil penyesuaian diri mahasiswa dalam proses pembelajaran.

Dalam buku Pedoman Akademik STAB Kertarajasa (2016), Indeks Prestasi (IP) adalah nilai kredit rata-rata yang merupakan satuan nilai akhir yang menggambarkan mutu penyelesaian suatu progam pendidikan pada satu semester. Indeks prestasi dihitung pada setiap akhir semester dan pada akhir progam pendidikan yang hasilnya disebut Indeks Prestasi Kumulatif (IPK). Indeks Prestasi Kumulatif merupakan ukuran kemampuan mahasiswa sampai pada periode tertentu yang dihitung berdasarkan jumlah SKS (Satuan Kredit Semester) tiap mata kuliah yang telah ditempuh (Prijana \& Yanto, 2018).

Ukuran nilai tersebut akan dikalikan dengan nilai bobot tiap mata kuliah kemudian dibagi dengan jumlah SKS mata kuliah yang telah ditempuh dalam suatu periode tertentu. IPK dapat diperoleh berkat adanya kesepakatan antara dosen dan mahasiswa, biasanya diberikan sebelum awal perkuliahan berlangsung. Penilaian prestasi mahasiswa dalam suatu Mata kuliah dilakukan dengan menggunakan lambang huruf dan angka yang rentanganya berkisar dari 0.00 sampai 4.00 .

\section{Prestasi non akademik}

Menurut Mulyono (2008) bahwa kegiatan ektrakurikuler adalah kegiatan yang dilaksanakan di sekolah untuk mencapai tujuan-tujuan pendidikan tertentu yang tidak direalisasikan dalam pelajaran biasa, oleh karena itu dibutuhkan alokasi waktu yang khusus untuk kegiatan tersebut. Lebih jauh 
dijelaskan prestasi non akademik merupakan prestasi atau kemampuan yang dicapai siswa dari kegiatan di luar jam pelajaran atau dapat disebut dengan ektrakurikuler. Kegiatan tersebut bertujuan untuk memberikan kesempatan kepada peserta didik untuk mengembangkan bakat, potensi, minat atau hobi yang dimilikinya.

Menurut Syah (Syafi'i, Marfiyanto \& Rodhiyah, 2018) terdapat tiga aspek dalam prestasi belajar yakni: ranah kognitif, afektif, dan psikomotor. Pertama aspek kognitif, aspek kognitif sebagai indikator dalam pencapaian sebuah prestasi menujukkan bahwa untuk mengukur prestasi siswa pada bidang kognitif dapat dilakukan dengan berbagai cara, baik dengan tes tulis maupun tes lisan. Aspek kognitif dikelompokkan menjadi enam tingkatan yaitu (Syafi'i, Marfiyanto \& Rodiyah, 2018):

1.Tingkat pengetahuan (knowledge), tujuan intruksional pada level ini menuntut peserta didik untuk mengingat (recall) informasi yang telah diterima sebelumnya, misalnya fakta, terminologi pemecahan masalah.

2. Tingkat pemahaman (komprehensip), kategori pemahaman dihubungkan dengan kemampuan-kemampuan untuk menjelaskan pengetahuan, informasi yang telah diketahui dengan kata-kata sendiri. Dalam hal ini peserta didik diharapkan menerjemahkan kembali apa yang telah didengar dengan kata-kata.

3. Tingkat penerapan (application), penerapan merupakan kemampuan untuk menggunakan atau menerapkan informasi yang telah dipelajari ke dalam situasi yang baru, serta memecahkan berbagai masalah yang timbul dalam $\mathrm{k}$ e hi d u pa n s e h a i - h a r i .

4. Tingkat analisis (analysis), analisis merupakan kemampuan untuk mengidentifikasi, memisahkan dan membiarkan komponen-komponen atau elemen-elemen suatu fakta, konsep, pendapat, asumsi, hipotesa atau kesimpulan dan memeriksa komponen-komponen tersebut untuk melihat ada atau tidaknya $\begin{array}{llllllllllllllllllll}k & o & n & t & r & a & d & i & k & s & i\end{array}$.

5. Tingkat sintesis (synthesis), sintesis diartikan sebagai kemampuan seseorang dalam mengaitkan dan menyatukan berbagai elemen dan unsur pengetahuan yang ada sehingga terbentuk pola baru yang menyeluruh.

6. Tingkat evaluasi (evaluation), evaluasi merupakan level tertinggi yang mengharapkan siswa mampu membuat penilaian dan keputusan tentang nilai gagasan metode produk atau benda dengan menggunakan kriteria

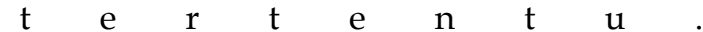

Kedua aspek afektif, meliputi watak perilaku seperti perasaan, minat, sikap, emosi, atau nilai. Ranah afektif menentukan keberhasilan belajar seseorang. Orang yang tidak memiliki minat pada pelajaran tertentu sulit untuk mencapai keberhasilan studi secara optimal. Seseorang yang berminat dalam suatu mata pelajaran diharapkan akan mencapai hasil belajar yang optimal. Syah (2004) mengatakan bahwa prestasi yang bersifat efektif yaitu meliputi penerimaan sambutan, apresiasi (sikap menghargai), internalisasi (pendalaman), karakterisasi (penghayatan), contohnya adalah siswa mampu menunjukkan sikap menerima dan bersikap berpartisipasi.

Ketiga aspek psikomotor, aspek ini merupakan aspek yang berhubungan dengan olah gerak seperti yang berhubungan dengan otot-otot syaraf, misalnya lari, melangkah, menggambar, berbicara. Gerakan dasar adalah mengarah pada keterampilan komplek yang khusus. Siswa yang telah mencapai kompetensi dasar pada ranah ini mampu melakukan tugas dalam bentuk keterampilan sesuai dengan standar atau kriteria.

\section{METODE PENELITIAN}

Penelitian dilaksanakan di Sekolah Tinggi Agama Buddha (STAB) Kertarajasa Batu, Jawa Timur. Pendekatan yang digunakan berupa pendekatan kuantitatif dengan desain penelitian eksperimen. Perlakuan yang diberikan terdiri atas self-management pada mahasiswa Samanera/Atthasilani dan reguler dengan tipe uji yang digunakan adalah $\mathrm{t}$ test dalam mencari pengaruh. Data primer diperoleh dari hasil pengamatan atau pencatatan oleh peneliti secara langsung di lokasi penelitian. Sedangkan data sekunder (penunjang) didapat dari dokumendokumen yang mendukung untuk penelitian, seperti buku, jurnal, artikel, website, serta KHS mahasiswa yang ada kaitannya dengan penelitian yang dilakukan. Penelitian ini terdiri atas dua variabel, variabel bebas $(\mathrm{X})$ yaitu self-management yang terdiri atas self-management untuk Samanera/Atthasilani dan reguler, dan variabel terikat yaitu prestasi belajar (Y). Penelitian ini dilakukan kepada mahasiswa dengan program Samanera/Atthasilani dan reguler Sekolah Tinggi Agama Buddha (STAB) Kertarajasa yang berjumlah 28 mahasiswa yang diambil secara acak. Keseluruhan partisipan itu terdiri atas 14 mahasiswa Samanera/Atthasilani dan 14 mahasiswa reguler, untuk kelompok mahasiswa Samanera terdiri atas 7 orang 
dan kelompok Atthasilanī 7 orang. Instrumen yang digunakan berbentuk pertanyaan tertulis (angket) yang dipersiapkan sesuai dengan tujuan penelitian. Untuk memberikan penilaian terhadap item-item pada daftar pertanyaan, dapat dilakukan dengan memberikan skor pada pernyataan. Data nilai IPK diperoleh dari bagian pendidikan mahasiswa Sekolah Tinggi Agama Buddha (STAB) Kertarajasa. Data yang terkumpul ditabulasi, kemudian dianalisis dengan menggunakan skala likert untuk mengetahui respon responden terhadap tingkat self-management. Dalam analisis skala likert terdapat dua cara yaitu menggunakan garis kontinum dan persen pencapaian. Selain itu untuk mencari perbedaan pengaruh antara self-management mahasiswa Samanera/Atthasilani dengan self-management mahasiswa reguler digunakan uji t dengan beberapa tahap di antaranya; menyusun hipotesis, kriteria uji, dan kesimpulan melalui membandingkan $\mathrm{t}$ hitung dengan $\mathrm{t}$ tabel.

\section{HASIL DAN PEMBAHASAN}

\section{Hasil}

Tabel 1.Tingkat Self-management Mahasiswa Samanera/ Atthasilani dan Reguler

\begin{tabular}{lccc}
\hline $\begin{array}{l}\text { Macam } \\
\text { Analisis }\end{array}$ & kor Total & Kriteria & $\begin{array}{c}\% \\
\text { capaian }\end{array}$ \\
\hline $\begin{array}{l}\text { a. Secara } \\
\text { Keseluruhan }\end{array}$ & 698 & E & $76 \%$ \\
\hline $\begin{array}{l}\text { b. Secara Parsial } \\
\text { self-motivation }\end{array}$ & 288 & SE & $86 \%$ \\
self-organization & 321 & SE & $95 \%$ \\
self-control & 335 & SE & $99 \%$ \\
self-development & 255 & SE & $76 \%$ \\
\hline
\end{tabular}

Dari Tabel 1. tersebut ternyata bahwa tingkat self-management secara keseluruhan dan parsial mempunyai kriteria sampel efektif (SE). Skor secara keseluruhan sebesar 1698 dengan persen capaian 76\% dari yang diharapkan atau ideal (100\%), sedangkan secara parsial yang memiliki self-motivation, selforganization, self-control, dan self-development masingmasing mempunyai skor sebesar 288, 321, 335, 285 dengan kriteria keempatnya sangat efektif (SE) dengan persen capaian masing-masing 86\%, 95\%, 99\%, 76\% dari yang diharapkan (100\%). Kesimpulannya yaitu bagaimana mempertahankan prestasi yang sudah tergolong sangat efektif tersebut.

Hasil Prestasi Belajar Mahasiswa Samanera/ Atthasilani dan Reguler STAB Kertarajasa.
Tabel 2. Hasil Prestasi Belajar Mahasiswa

Nilai IPK

rata-rata

\begin{tabular}{lllccc}
\hline $\begin{array}{l}\text { Sama } \\
\text { nera/ }\end{array}$ & reguler & Selisih & $\begin{array}{c}\mathrm{t} \\
\text { hitung }\end{array}$ & $\begin{array}{c}\mathrm{t} 0,05 \\
(\mathrm{db}=26)\end{array}$ & $\begin{array}{l}0,01 \\
\mathrm{db}=26)\end{array}$ \\
$\begin{array}{l}\text { Attha } \\
\text { silani }\end{array}$ & & & & & \\
\hline 3,494 & 2,952 & 0,542 & $2,564^{*}$ & 2,056 & 2,779 \\
\hline
\end{tabular}

$\left.{ }^{* *}\right)$ - sangat nyata

Dari Tabel 2 tersebut menunjukkan bahwa ada perbedaan yang nyata antara IPK mahasiswa Samanera/Atthasilani dengan reguler karena t hitung $(2,564)>$ t $0,05=2,056<$ t 0,01 $(=2,779)$. Terlihat bahwa IPK Samanera/Atthasilani lebih tinggi daripada mahasiswa reguler.

\section{Pembahasan}

Hasil penelitian menunjukkan bahwa tingkat self-management mahasiswa (Samanera/Atthasilani dan Reguler STAB Kertarajasa) Tahun Akademik 2020/2021 tergolong sangat efektif. Dalam hal ini dapat diartikan bawa individu mampu memotivasi, mengorganisasi diri, mengatur, dan memaksimalkan kemampuan diri dengan baik. Hasil dari evaluasi total secara keseluruhan dan parsial mempunyai kriteria sampel efektif (SE). Skor secara keseluruhan sebesar 1698 dengan persentase capaian 76\% dari yang diharapkan atau ideal (100\%), sedangkan secara parsial yang memiliki self-motivation, self-organization, self-control, dan self-development masing-masing mempunyai skor sebesar 288, 321, 335, 285 dengan kriteria keempatnya sangat efektif (SE) dengan persentase capaian masing-masing 86\%, 95\%, 99\%, $76 \%$ dari yang diharapkan (100\%). Hal ini dapat terjadi karena mahasiswa STAB Kertarajasa sejak masuk ke perguruan tinggi sudah diajarkan untuk dapat mandiri dengan memberikan bekal berupa pelatihan-pelatihan yang berkitan dengan management semenjak menjadi mahasiswa baru. Rencana belajar, program studi, dan jadwal kegiatan akademik lainnya yang telah ditetapkan, selain itu kegiatan-kegiatan yang ada STAB Kertarajasa dan Padepokan Dhammadipa Arama sudah terstruktur jadi mahasiswa memudahkan membagi waktu antara kegiatan akademik dan kegiatan non akademik. Mahasiswa STAB Kertarajasa memiliki mahasiswa dari berbagai daerah menuntut ilmu dalam mengembangkan agama Buddha di daerahnya, yang kemudian menjadikan motivasi hidup mandiri dalam menempuh pendidikan. Jadi sudah jelas bahwa tingkat Self-management mahasiswa dalam memotivasi, mengorganisasi, mengatur, dan memaksimalkan kemampuan diri dapat dikatakan 
sangat efektif

Berdasarkan penelitian pengaruh selfmanagement terhadap prestasi belajar bahwa terdapat perbedaan nilai rata-rata IPK (indeks prestasi komulatif) mahasiswa Samanera/Atthasilani terhadap nilai rata-rata IPK (indeks prestasi komulatif) yaitu sebesar 3,494 dengan mahasiswa reguler sebesar 2,952. Dapat diketahui bahwa t-hitung terletak pada daerah nyata dengan skor 2,564. Melalui perbandingan nilai IPK (indeks prestasi komulatif) dengan selfmanagement mahasiswa Samanera/Atthasilani dan dibandingkan dengan self-management mahasiswa reguler yang menunjukkan adanya suatu perbedaan pengaruh yang nyata antara self-management Samanera/ Atthasilani dengan reguler. Dari perhitungan yang dilakukan dapat ditarik kesimpulan bahwa mahasiswa Samanera/Atthasilani memiliki self-management lebih baik daripada mahasiswa reguler.

Hal ini karena terdapat perbedaan yang mencolok antara mahasiswa Samanera/Atthasilani dan mahasiswa reguler. Dari segi kehidupan mahasiswa Samanera/Atthasilani merupakan orang yang berlatih menjalankan sila (Samanera 10 sila) dan Atthasilani 8 sila). Mereka tinggal di Padepokan Dhammadipa Arama dengan tanggungan segala administrasi kampus dan segala bentuk kebutuhan (papan, pangan, sandang) yang ditanggung oleh pihak vihara sehingga mahasiswa Samanera/Atthasilani harus mengikuti aturan-aturan yang berlaku. Samanera/Atthasilani selain dituntut untuk dapat mengendalikan diri melalui pelatihan sila juga diajarkan untuk bergabung dalam organisasi-organisasi kecil seperti organisasi kelurahan, panitia-panitia ketika ada hari raya besar dan dalam tugas tugas tertentu. Ini akan membuat mereka terlatih untuk memimpin dirinya sendiri dan bahkan bisa memimpin orang lain.

Samanera/Atthasilani tidak hanya mendapat teori di kampus tetapi juga bisa mempraktikkan teori yang didapat ketika menjadi Samanera/Atthasilani. Inilah yang tidak didapatkan oleh mahasiswa reguler mereka harus mencukupi kebutuhan-kebutuhan pribadi dengan bekerja paruh waktu di samping itu juga dengan tidak adanya aturan dalam hal ini lebih bebas akan sulit untuk mengatur waktu dengan baik. Untuk mahasiswa reguler kemungkinan waktu belajar belum intens dibandingkan dengan Samanera/Atthasilani. Mahasiswa reguler masih mempunyai waktu yang digunakan untuk keperluan atau kegiatan yang lain seperti halnya berolahraga, liburan, dan bekerja.

Self-management merupakan salah satu penentu dari keberhasilan dalam menempuh pendidikan. Dalam proses belajar mengajar self-management sangat besar peranannya terhadap prestasi belajar. Karena dengan adanya self-management yang baik maka kegiatan belajar akan lebih sistematis sehingga akan berpengaruh terhadap peningkatan prestasi belajar siswa.

\section{PENUTUP}

\section{Kesimpulan}

Berdasarkan analisis skala likert tingkat self-management secara keseluruhan dan parsial mempunyai kriteria sampel efektif (SE). Skor secara keseluruhan sebesar 1698 dengan persentase capaian $76 \%$ dari yang diharapkan atau ideal (100\%), sedangkan secara parsial yang memiliki self-motivation, self-organization, self-control, dan self-development masing-masing mempunyai skor sebesar 288, 321, 335, 285 dengan kriteria keempatnya sangat efektif (SE) dengan persentase capaian masing-masing 86\%, 95\%, 99\%, 76\% dari yang diharapkan (100\%). Hasil penelitian menunjukan bahwa tingkat self-management mahasiswa (Samanera/Atthasilani dan reguler STAB Kertarajasa) tahun akademik 2020/2021 termasuk dalam kategori tinggi dalam arti mampu untuk mengatur diri dengan baik.

Berdasarkan uji t menunjukkan prestasi belajar dalam nilai IPK mahasiswa Samanera/Atthasilani lebih baik dari pada mahasiswa reguler, masing-masing sebesar 3,494 dan 2,952 yang menunjukkan hasil perbedaan yang nyata dengan $t$ hitung 2,564 . Hal ini karena Samanera/Atthasilani memiliki disiplin yang lebih baik daripada mahasiswa reguler.

\section{Saran}

Pihak kampus perlu memaksimalkan potensi individu melalui meningkatkan sarana dan prasarana serta pembekalan-pembekalan yang berkaitan dengan pengelolaan diri dalam bentuk pengetahuan dan pelatihan-pelatihan. Self-management mahasiswa sudah sangat efektif, tinggal bagaimana mempertahankan nilai yang sudah baik, untuk IPK mahasiswa perlu ditingkatkan lagi, terutama bagi mahasiswa reguler dapat dilakukan dengan meningkatkan selfmanagement. Bagi penelitian selanjutnya diharapkan dapat mengembangkan penelitian ini dengan meneliti self-management antara mahasiswa Samanera dan Atthasilani. Para pembaca diharapkan dapat memahami isi artikel dan dapat ditanamkan dalam kehidupan sehari-hari. Self-management sangat penting untuk menunjang kelancaran dalam setiap menghadapi permasalahan-permasalahan yang ada, selain itu self-management juga akan mempermudah 
mencapai goal yang ditetapkan dari individu yang bersangkutan.

\section{DAFTAR PUSTAKA}

Agustiningrum, R., \& Kusbaryanto, K. (2019). Efektifitas Diabetes Self Management Education Terhadap Self Care Penderita Diabetes Mellitus: A Literature Review. Jurnal Keperawatan Respati Yogyakarta, 6(2), 558. https:// doi.org/10.35842/jkry.v6i2.309

Anwar, Saiful. (2017). Perilaku Mahasiswa Jurusan Ilmu Perpustakaan dalam Menyelesaikan Tugas-tugas Mata Kuliah. Skripsi: UIN Alauddin Makassar. http://repositori.uin-alauddin.ac.id/4567/1/SAIFUL\%20ANWAR. $\mathrm{p}$ $\mathrm{d}$

Ariyanti, Ita. (2010). Pengaruh Minat dan Motivasi Belajar terhadap Prestasi Belajar Mahasiswa Program Studi Pendidikan Akuntansi Universitas Negeri Semarang Angkatan 2008/ 2009. Skripsi: Universitas Negeri Semarang. http://lib.unnes.ac.id/5215/1/6382_A.pdf

Basri, Said Hasan. (2012). Prestasi akademik ditinjau dari kemampuan literasi media. Jurnal Dakwah, XIII(1), 15-38. http:/ / ejournal.uin-suka. ac.id/dakwah/jurnaldakwah/article/view $\begin{array}{llll}\text { / } & 3 & 1 & 7\end{array}$

Bodhi. (2000). The Connected Discourses of the Buddha Vol.1 (Samyutta Nikaya) Oxford; The Pali Text $\begin{array}{lllllllll}\mathrm{S} & \mathrm{o} & \mathrm{c} & \mathrm{i} & \mathrm{e} & \mathrm{t} & \mathrm{y} & \text {. }\end{array}$

Diputhera, Oka. (2004). Meditasi II. Jakarta. Vajra $\mathrm{D} \mathrm{h}$ a r m a $\quad \mathrm{Nus}$ a $\mathrm{nt}$ a $\mathrm{r}$

Frayne, C.A. \& Geringer, J. M. (2000). Self-Management Training for Imroving Job. Performance: A Field Expriment Involving Salespeople. Journal of Applied Psychology, 85, 361-372. https://kbbi.web.id/manajemen diakses pada tanggal 20 februari 2020, pukul 20.20.

Gie, T. L. (2000). Cara Belajar Yang Baik Bagi Mahasiswa Edisi Kedua, Yogyakarta: Gadjahmada $\mathrm{U} n \mathrm{i} v$ e $\mathrm{r}$ s i t y P r e s s.

Jazimah, H. (2014). Implementasi Manajemen Diri Mahasiswa dalam Pendidikan Islam. Mudarrisa: Jurnal Kajian Pendidikan Islam, 6(2), 221-250. DOI: https://doi.org/10.18326/mdr. $\mathrm{v} \quad 6 \quad \mathrm{i} \quad 2 \quad \begin{array}{llllllll} & 2 & 2 & 1 & - & 2 & 5 & 0\end{array}$

Khoiratunnisaa, N. S. (2016). Manajemen Diri Pada Mahasiswi Berprestasi Yang Bekerja (Studi Kasus Pada Satu Mahasiswi D3 Bahasa Inggris Universitas Gadjah Mada). Yogyakarta: Universitas Islam Negeri Sunan Kalijaga. Lestariningsih, W.S. (2007). Prokastinasi Akademik
Mahasiswa Ditinjau dari Efikasi Diri dan Dukungan Sosial. Skripsi. Surakarta: Fakultas

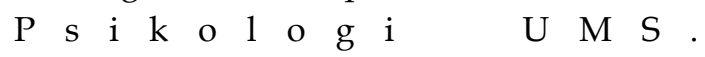
Mehm, T.M. (2012). Intisari Jalan Kesucian (Visuddhi Magga). Medan: Indonesia Tipitaka Center $\left(\begin{array}{llll}\mathrm{I} & \mathrm{T} & \mathrm{C}\end{array}\right)$ Mulyono. (2008). Manajemen administrasi dan organisasi pendidikan. Yogyakarta: Ar-ruzzm e d d i a

Ningsih, A. F. (2018). Orientasi Agama para Samanera dan Atthasilani di Vihara Dhammadipa Arama, Mojorejo, Kota Batu, Malang, Jawa Timur. RELIGI: Jurnal Studi Agama-Agama, 14(1), 115-132. DOI: https://doi.org/10.14421/ r e j u s t a . $2018.1401-06$

Penterjemah. 2013. Kitab Suci Dhammapada. Tanpa Kota: Bahusutta Society. Prijana, P. \& Yanto, A. (2018). Analisis hubungan Prestasi Akademik Mahasiswa dengan Akses Sumber Informasi. Berkala Ilmu Perpustakaan Dan Informasi, 14(1), 87-94. https:/ / doi.org/ $10.22146 /$ b i p . 17501 Rachmahana, R. A. (2002). Perilaku Prokrastinasi Akademik pada Mahasiswa. Psikodimensia Kajian Ilmiah Psikologi, 2(3), 132-137. Rengginas, D. R. P. (2005). Peran manajemen diri dan kematangan emosi dengan pengambilan keputusan, Yogyakarta: Sekolah Pascasarjana Fakultas Psikologi UGM, Retnowati, D. R., Fatchan, A., \& Astina, I. K. (2016). Prestasi Akademik Dan Motivasi Berprestasi Mahasiswa S1 PendidikaN Geografi Universitas Negeri Malang. Jurnal Pendidikan: Teori, Penelitian dan Pengembangan, 1(3), $\begin{array}{lllllll}5 & 2 & 1 & - & 5 & 2 & 5\end{array}$.

Sarafino, E. P. (2010). Self-management: Using behaviour and cognitive principles to manage your life. London: John Wiley \& Son Sayadaw, T. M. (2008). Riwayat Agung Para Buddha. Tanpa Kota: Ehipassiko Foundation \& Giri M a ng a la Public a tions. Slameto. 2003. Belajar Dan Faktor-Faktor Yang Mempengaruhi. Jakarta: Rineka Cipta. Syafi'i, A. \& Marfiyanto, T. \& Rodiyah, S. K. (2018). Studi tentang Prestasi Belajar Siswa dalam Berbagai Aspek dan Faktor yang Mempengaruhi. Jurnal Komunikasi Pendidikan, 2(2), 115-123. DOI: https://doi.org/10.32585/jkp. $\begin{array}{llllllll}\mathrm{v} & 2 & \mathrm{i} & 2 & \text {. } & 1 & 1 & 4\end{array}$ Syah, M. (2010). Psikologi Belajar. Jakarta: PT Rajag r a f i n d o P e r s a d a. Tim Penyusun. (2016). Buku Pedoman Akademik 
Program Studi Dharma Acarya. Batu: Sekolah

Tinggi Agama Buddha (STAB) Kertarajasa.

Wijoyo, H., \& Surya, J. (2020). Analisis Penerapan

Meditasi Samatha Bhavana di Masa Covid-19

Covid-19 terhadap Kesehatan Mental Umat

Buddha. SEJ: School Education Journal, 10(2),

121-130. DOI: https://doi.org/10.24114/sej-

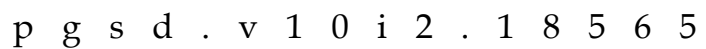

Yenni, D. (2007). Kuliah Sambil Kerja Why Not. Medan:

$\mathrm{M}$ e $\mathrm{d}$ a $\mathrm{n} \quad \mathrm{b}$ i $\mathrm{s} \mathrm{n}$ i $\mathrm{s}$

Yuen, M. (2008) Psichology Of Education (3rd Ed).

New York: The Guilford Press 